\title{
Analysis of flood occurrence seasonality on the Czech Republic territory with directional characteristics method
}

\author{
RADEK ČEKAL, JOSEF HLADNÝ
}

Czech Hydrometeorogical Institute

\begin{abstract}
Analysis of flood occurrence seasonality represents one of ambitious methodological approaches oriented towards enhancing knowledge on regime of these natural disturbances. Data from 181 gauging stations (out of them 108 in the Labe River Basin, 21 in the Odra River Basin and 52 in the Morava River and the Dyje River Basins) were applied for analysis on the Czech Republic territory. The input data were flood discharges represented by their daily averages within the reference period 1975-2000. Method of directional statistic was used to express spatial dissimilarity of flood occurrence seasonality. Output resulting from application of this method is determination of the flood occurrences mean day (MD) within the year in the examined river basin and furthermore the time dispersion index $(r)$ of flood events.

Based on these directional characteristics applied on sets of selected river basins, the Czech Republic territory can be divided into regions according to flood occurrence frequency in particular period of year.
\end{abstract}

Key words: Flood occurrence - flood seasonality - seasonal analysis - directional statistics - flood regionalization

\section{Introduction}

Knowledge of regionalization of maximum discharge occurrence seasonality is an important source for flood protection from the point of view of flood disaster load in individual river basins, furthermore for recognizing mechanisms of flood event evolution, for development of frequent analysis for derivation of design hydrologic data and for improving knowledge on flood regime in the landscape in general. Regional analysis is often used even for improving probability occurrence assessments of extreme flood discharges in localities with relatively short observation periods in comparison with assessed flood recurrence period, or in regions without observations where it is necessary used for extreme flood characteristic assessments data from similar river basins having existing observations. (Burn 1997; Black, Werrity 1997).

In the Czech Republic there were already similar studies worked out in the past and they showed both differences and even certain identical features in different river basins from the flood seasonality point of view (Brádka 1967; Hladný 1971; Buchtele 1972; Kakos 1983, 1985; Kašpárek 1999; Vavruška 1989). In this contribution, however, there are not studied flood occurrence seasonal characteristics in the 
selected individual river basins advance as in the above mentioned studies, but hydrological homogenous regions are identified on the base of seasonal characteristic similarity of extreme flood occurrences.

\section{Flood seasonality}

The floods arising from cyclonic and frontal precipitation have their meteorological origins located mostly beyond the river basin in question. The causal atmospheric circulation and the connected precipitation activity is influenced in the ground layer also by other specific physical-geographic conditions in the river basin. These conditions are different in the landscape and therefore they are influenced by meteorological factors differently, it means that each river basin can be sensitive differently to the same kind of meteorological conditions or to their successive combinations.

Considering the outflow response similarity in smaller river basins as indicator, than individual river basins can be grouped into regions. Their defining asks for similar characteristic value in the framework of one region and on the other hand for mutual dissimilarities of different regions.

In this study as a measure of the river basin similarity served just the seasonal characteristic of the flood occurrences within the annual cycle. Different results of seasonal analysis in selected river basins enable to define regions on the Czech Republic territory theirs specific natural conditions predetermine, or at least contribute to flood occurrence in the particular period of year.

\section{Selection and preparation of data}

Database collected for this study was compiled from discharges observed in gauging stations. The main criterion for their selection was the uninterrupted series, the existence of uninfluenced natural outflow regime and the existence of the reliable quality of data. Only 181 gauging stations out of all gauging stations in the Czech Republic satisfied these selected conditions. 108 of them are in the Labe River Basin, 21 in the Odra River Basin and 52 in the Morava River and the Dyje River Basins see Fig. 1. In this set of data stations with relatively smaller river basins dominate. They belong mostly to the head and the middle stretches of rivers.

For seasonal flood occurrence analysis the hydrologic data from the Czech Hydrometeorological Institute (CHMI) were used and particularly those with the daily step available. If the hourly step was applied the number of selected stations respecting chosen criteria would decrease. The input data were thus the average daily discharge values during the flood episode. For each of the 181 selected gauging stations the series of these discharges from the unified reference period 1975-2000 was employed.

Before application of the selected seasonal analysis on discharge series in selected gauging stations, it was necessary to eliminate cases of accidental local spillings which could distort the statistics of dominant floods. Based on the POT (Peaks Over 


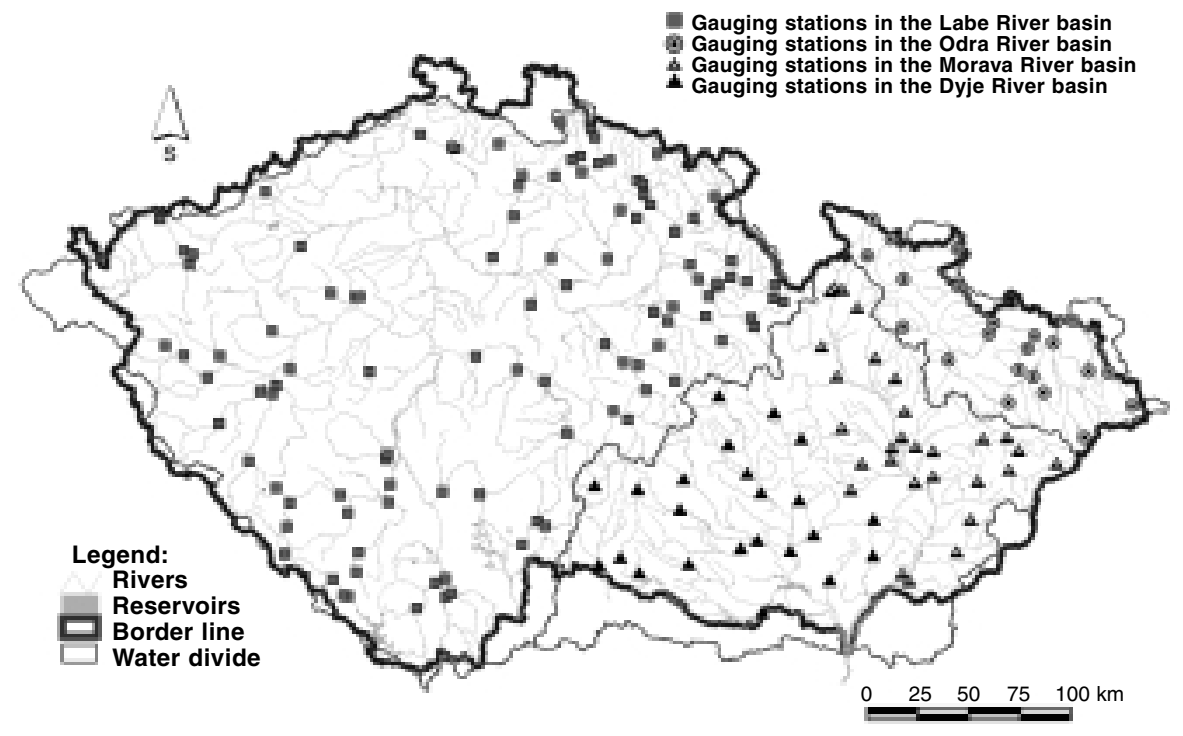

Figure 1: Location of selected gauging stations in the Czech Republic

Threshold) method, i.e. calculations with discharges over selected limit, only those average daily flood discharge values which exceeded the selected limit $Q_{B}$ were analysed (Todorovic and Zelenhasic 1970). Gained experience shows that if $Q_{B}$ is selected too low than even cases of flood waves arising from local convective rains have a significant influence whereas the assessments of flood origin and development are based more on frontal rains. On the contrary, if we use the threshold responding to the discharge when water spills the river channel (Stage of Emergency), than the number of selected flood events is low. From the practical point of view, as the acceptable limit between these two possibilities, the value of the 1 year discharge was chosen.

These over average discharges are defined for all $Q_{v}$ in corresponding time periods with $\tau_{\Delta Q}$, for which is valid that:

$$
\left(Q_{v}-Q_{B}\right)=\Delta Q>0,
$$

so that all $Q_{v}$ in the interval $<0, Q_{v} \leq Q_{B}>$, which have more or less accidental character, are exceeded: where $Q_{B}$ is the threshold discharge,

$Q_{v}$ are discharges in time $\tau$,

$\tau_{\Delta Q}$ is time with $\Delta Q>0$ occurrence.

The directional statistic method, using discharges separated by the POT method, was applied in this study to illustrate seasonal information included in applied database. 


\section{Directional statistic method}

To express spatial flood occurrence dissimilarity on the Czech Republic territory the directional statistic method was applied because it enables to work with data in the daily step and therefore to achieve an objective determination of the searched period with higher flood occurrence probability. Data obtained from discharge series from the selected gauging stations should represent the discharge regime even in the near vicinity of their river basins.

Application of directional characteristic method transforms the datum of flood occurrence with help of polar coordinate system into the corresponding location on the unit circle representing sequence of days during a year. Mathematical convention places the begining of year ( $1^{\text {st }}$ January) in the most eastern point of this circle. Individual year seasons follow the the circle quadrants in anticlockwise direction (Mardia 1972; Fisher 1993). At the same time Bayliss and Jones (1993) converse the datum of the flood event occurrence $i$ into the expression:

$$
\phi_{i}=G D_{i}\left(\frac{2 \pi}{365}\right)
$$

where $\phi_{i}$ is angle value (in radians) for the datum of the flood event occurrence $i$, $G D_{i}$ is datum by the Gregorian calendar.

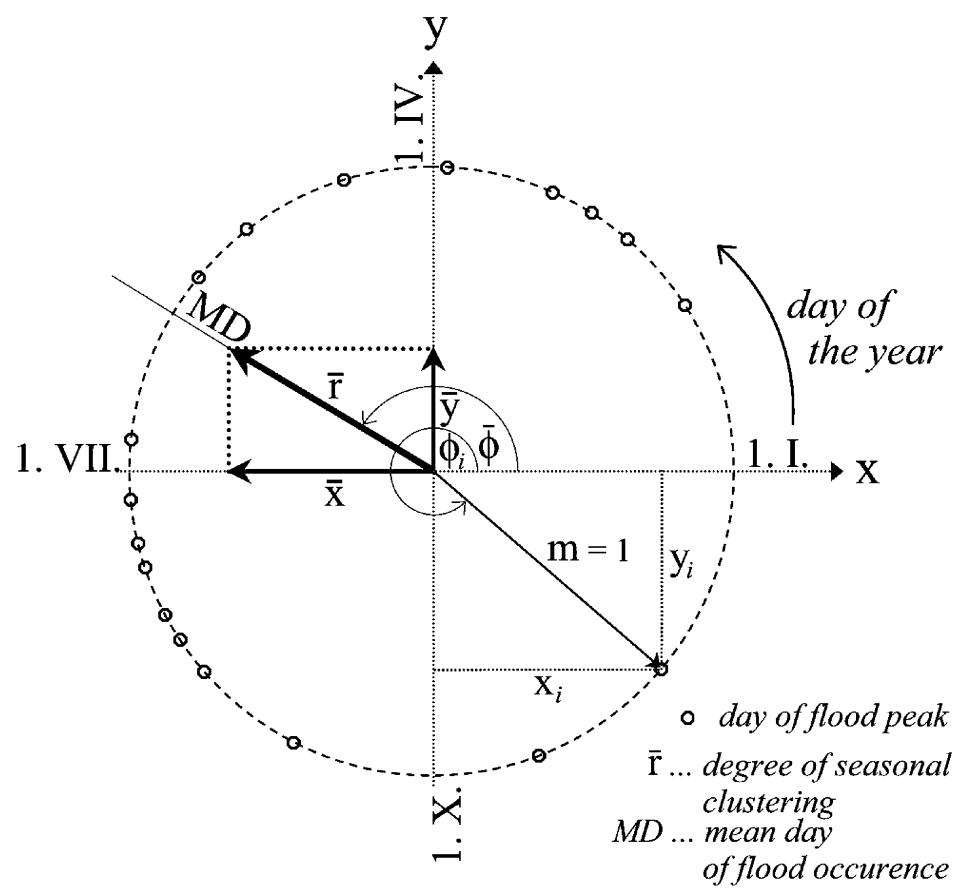

Figure 2: Determination of the mean day flood occurrence MD as the mean vector determined with the direction characteristic method by Black, Werritty (1997) 
In this way every datum of the peak discharge occurrence can be interpreted as directional vector (see Fig. 2) with angle and magnitude $m$ (the unit circle has always $m=1$ ). If we have a set of $n$ floods than coordinates and, in Cartesian system, of the flood occurrence mean day MD (Mean Day) in the selected profile can be defined as:

$$
\bar{x}=\frac{1}{n} \sum_{i=1}^{n} \cos \left(\phi_{i}\right) \quad \bar{y}=\frac{1}{n} \sum_{i=1}^{n} \sin \left(\phi_{i}\right)
$$

where $\bar{x}$ and $\bar{y}$ represent $x$ and $y$ coordinates of the flood occurrence

mean datum in the particular river basin.

The value of MD can be completed with measure of flood occurrence dispersion defined as:

$$
r=\sqrt{\bar{x}^{2}+\bar{y}^{2}}
$$

where $r$ serves as measure of flood occurrence time dispersion.

Values of $r$ close to one indicate the river basins with high seasonal flood response (the value $r=1$ would mean that all floods in the selected profile would take place in the same day of the year). On the contrary, the value close to zero shows the high response of flood event occurrences within the whole year.

Application of the direction statistics method has two main advantages. Firstly, it enables to express information on discharge seasonality with the only one numerical magnitude and, secondly, it enables to compare and to differentiate the selected areas according to their average occurrence of extreme daily discharges with accuracy of one day. On the other hand a certain disadvantage of this method is the possible loading of the seasonal information with the known error of averaging, i.e. that the same average can be obtained from different input value positions. Therefore the MD characteristic itself does not enable to determine explicitly if the flood occurrence regime is exclusively winter, summer or a mixed one. Only the combination MD with the characteristic $r$ can offer this full information. The distinguishing of river basins according to their flood occurrence seasonality is therefore based on the inseparable application of directional characteristics MD and $r$.

\section{Seasonal analysis of flood event occurrence}

To minimize load of directional statistics by the error arising from averaging, the seasonal analysis of flood event occurrences in selected profiles was worked out separately for two different parts of year. Definition of individual halves of year was governed with effort to divide periods when outflow conditions in the Czech rivers are basically influenced with snow cover and with further factors (frost soil, ice motion in rivers, etc.) which can modify the resulting outflow from river basins in winter period significantly. The distribution of flood occurrences in the period 1975-2000 is significantly asymmetric, as the Tab. 1 proves: 
Table 1: Monthly flood event occurrence frequency with culmination $\mathrm{Q}_{\max } \geq \mathrm{Q}_{1 \text { year }}$ in selected gauging stations in the Czech Republic territory during the period 1975-2000

\begin{tabular}{|c|c|c|c|c|c|c|}
\hline Month & I & II & III & IV & V & VI \\
\hline Sum of floods & 275 & 204 & 520 & 121 & 162 & 106 \\
\hline$\%$ & 11.8 & 8.8 & 22.4 & 5.2 & 7.0 & 4.6 \\
\hline Month & VII & VIII & IX & X & XI & XII \\
\hline Sum of floods & 332 & 201 & 52 & 49 & 46 & 254 \\
\hline$\%$ & 14.3 & 8.7 & 2.2 & 2.1 & 2.0 & 10.9 \\
\hline
\end{tabular}

April shows to be the transient month. With respect to gradual warming the division by Netopil (19984) was used to determine seasonality. He divides hydrological year into two parts: cold and vegetation ones. The winter part is determined by months from October to March, the summer part (vegetation) by months from April to September.

First, the seasonal analysis MD of flood events during the whole year was worked out. The results from examined data of the reference period 1975-2000 show, that as to the number of $\mathrm{MD}$ in individual months, the highest share of $\mathrm{MD}(24 \%)$ belongs to February which is followed by March (19\%), July (18\%) and April (12\%). On the other hand the lowest share (0.5) of determined MD is represented by autumn months September and October.

Seasonal analysis results of MD in the whole annual cycle are shown in Fig. 3. It is evident that in the Czech Republic river basins two different typical kinds of flood regime exist. The first kind has floods arising particularly at the end of winter and in the first spring months as the result of snow cover melting in combination with rainfall.

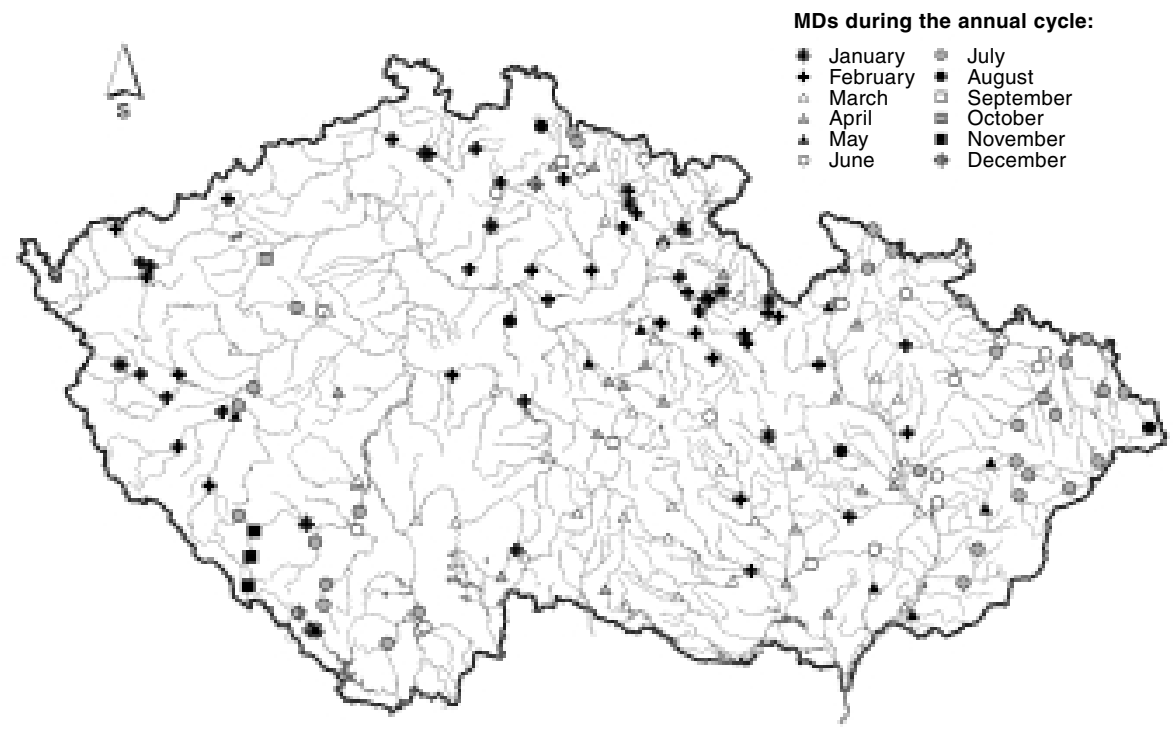

Figure 3: Presentation of mean annual flood events occurrence (MD) in selected profiles in individual months of the reference period 1975-2000 
The other typical kind is represented by summer rainfall floods occurring in summer months. In many river basins, however, even a mixed flood regime exists, i.e. that from the long-term point of view even many flood events occur both in summer and in winter halves of year.

The number of individual months with defined MD in selected profiles proves that the first kind of floods prevails in the Czech Republic territory. Higher flood occurrence of this kind is typical particularly for water courses in the Labe River Basin and the Českomoravská vrchovina (with exception of the upper Vltava and the Berounka River Basins and the Dyje River Basin) - see Fig. 3.

The summer period of the year represents more than one quarter of all MD flood events in the reference period in question. Flood unrest in these months is typical particularly for water courses in the Odra, the lower Morava, the Malše, the Otava, the upper Sázava, the middle Berounka and the upper Jizera River Basins.

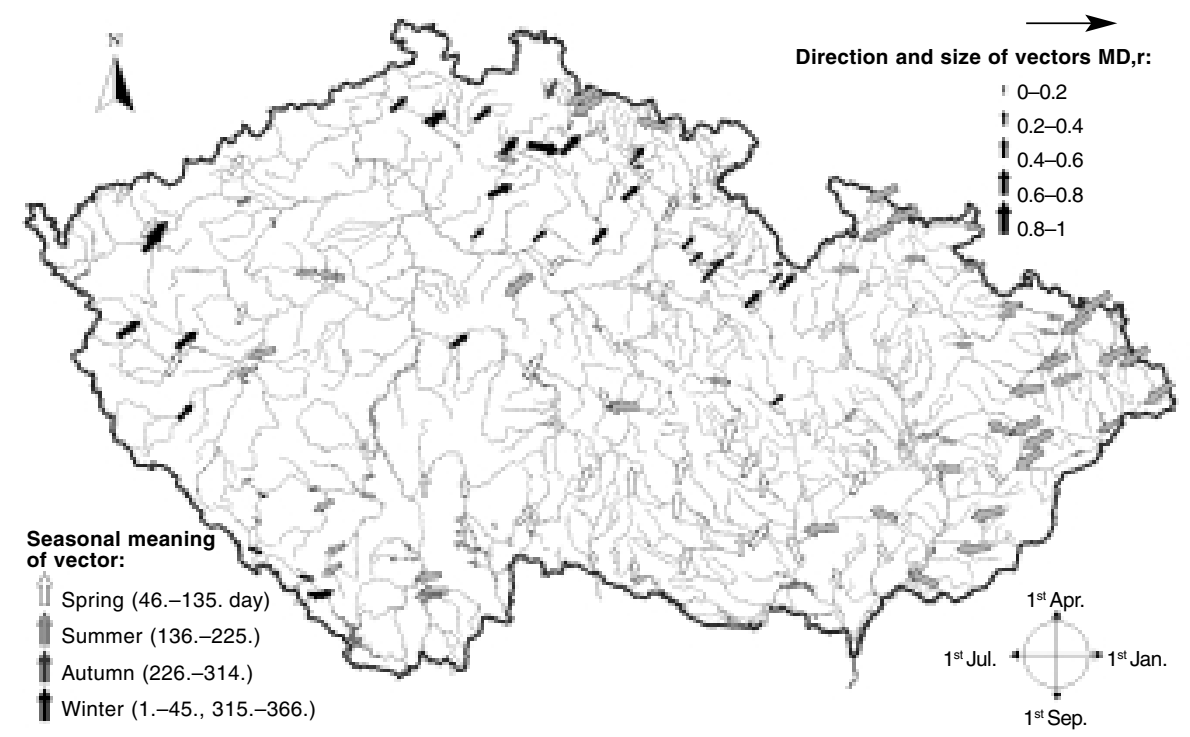

Figure 4: Presentation of mean annual flood events occurrence (MD) in year periods in selected profiles during the reference period $1975-2000$

The map in Fig. 4 shows a detail review of the whole annual flood occurrences in selected gauging stations. In the map the MD values are presented by directional vectors. Graphical differences of individual vectors offer information on the year period and on the river basin in which a certain MD datum occurs. Determination of year periods accepts the division by Netopil (1984). He considers as spring months March to May, summer months are June to August, autumn months September to November and winter months are December to February. In analysed profiles apart from information on time determination of MD even the measure of flood event occurrence dispersion may be assessed with help of the corresponding directional 
vector magnitude. High magnitudes of flood occurrence seasonal dispersion index $r$ going to 1 indicate the existence of relatively high seasonal component of flood regime with more frequent load of flood spilling in corresponding river basins. In the period 1975-2000 the highest magnitudes of the index, in average, were reached in the Odra River Basin (0.70). A significant seasonality occurred even in rivers in the Dyje River Basin (0.63) where floods in spring months prevail. On the contrary, relatively low flood event occurrence dispersions are typical for the greatest part of water courses in the Labe River Basin, where the average magnitude of the index $r$ reached 0.46 only. Low index magnitudes signalize that in the analysed water courses a mixed kind of floods prevails in greater measure.

Dispersion of examined MD in individual gauging profiles belonging to selected main river basins is highlighted in Fig. 5. Locations of individual MD in the unit circle show that the highest dispersions of MD are in gauging stations in the Labe River Basin; magnitudes of flood dispersion index $r$ are in these stations the lowest ones. At the same time in more than $50 \%$ of all tested stations the index value is lower than 0.5 (see their locations in the smaller circle). As the whole, the lowest time dispersion of flood occurrences belong to water courses in the Dyje and the Odra River Basins, where also the highest magnitudes of $r$ occurred.

In the next part of this study a seasonal analysis of flood events in two separate parts of the year in the reference period 1975-2000 was elaborated. With respect to

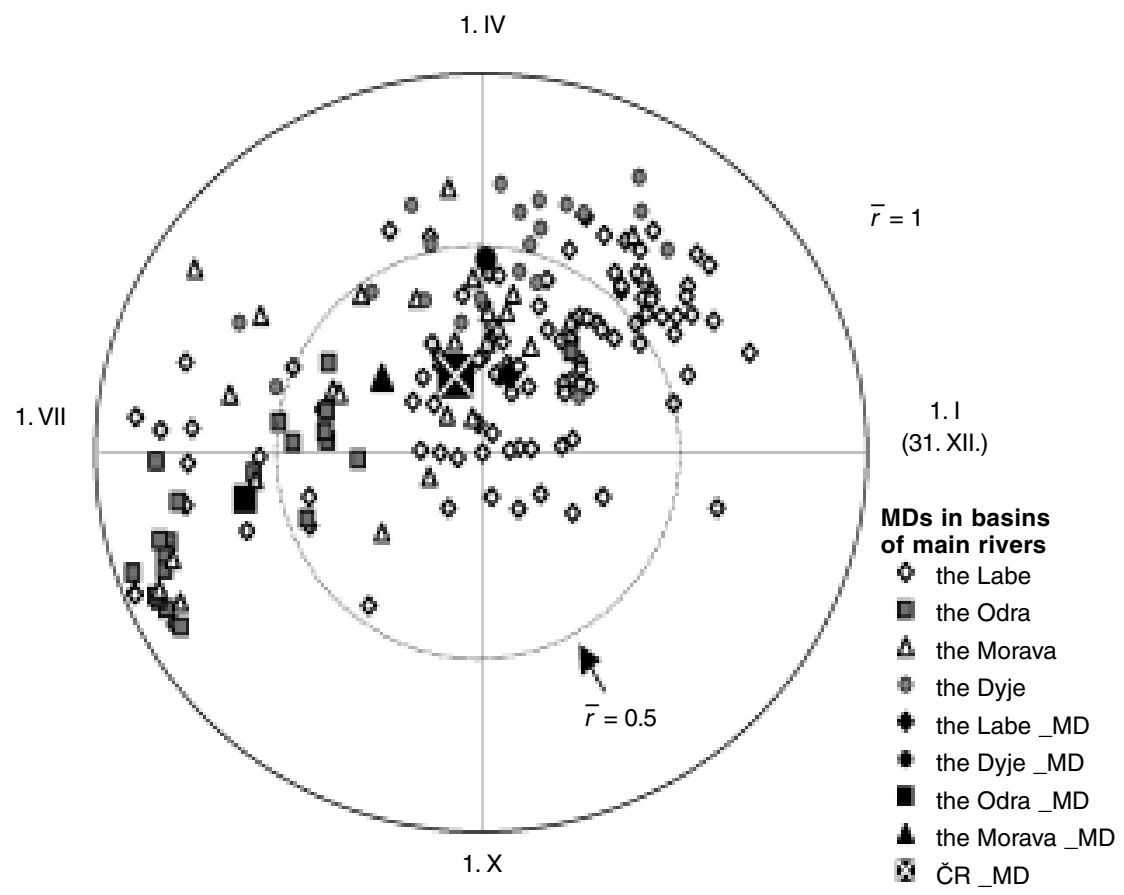

Figure 5: Presentation of average directional characteristics MD and $\mathrm{r}$ in the unit circle in selected profiles of main river basins with marking of their total average during the reference period 1975-2000 


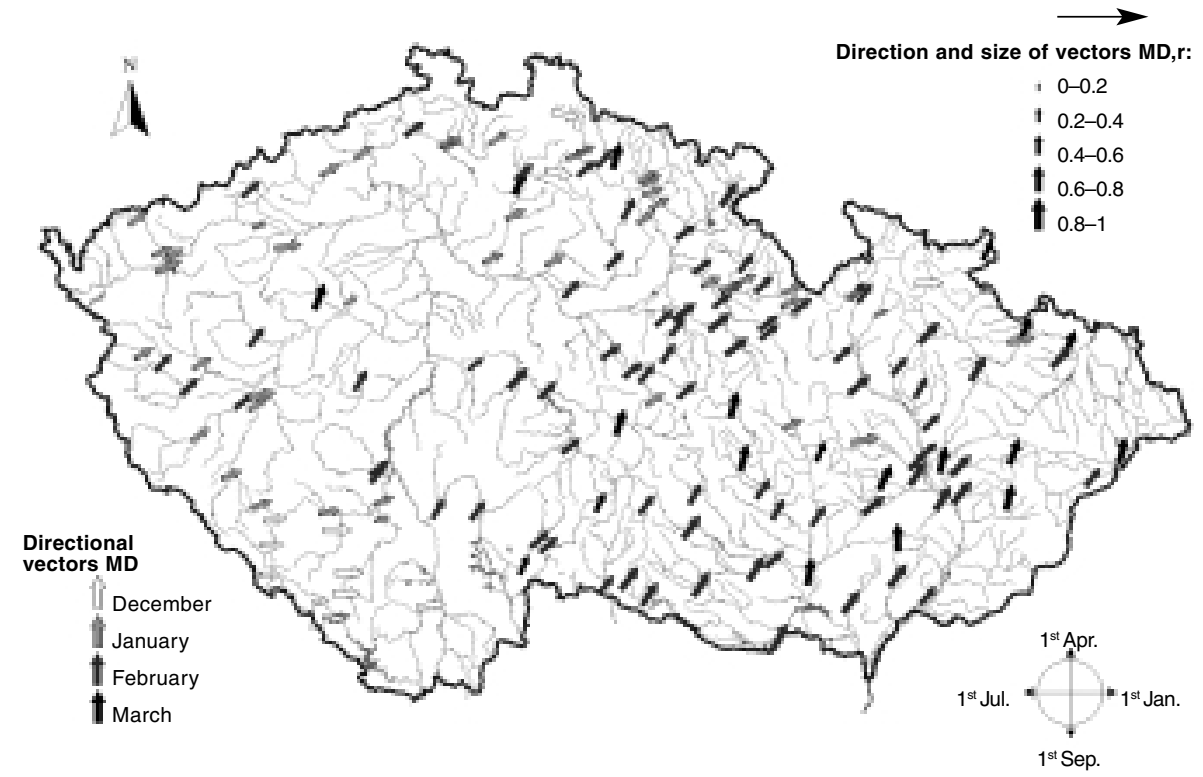

Figure 6: Presentation of average flood event occurrences (MD) in selected profiles in the winter period December to March during the reference period 1975-2000

obtained frequency of their occurrence during the year as the representatives of the winter regime data from months December to March were selected and for summer part the flood data from months May to August.

Application of directional characteristic analysis method on series of flood discharges in selected winter months offers Fig. 6. The average day of occurrence of winter flood events MD, calculated from data of all selected gauging stations, fell on the third decade of February (23 $3^{\text {rd }}$ February) and it represented a very half (50.3\%) of all considered flood events in the winter part of the year during the period 1975-2000. And even January had relatively very high portion of MD (29.4\%) with flood occurrences. Areal distribution of MD belonging to February was relatively even and with the highest density in the area of the Českomoravská vrchovina. On the contrary, the January MD data were located less evenly and these cases took place in boundary mountainous river basins, particularly in northern and western Bohemia. Number of MD with flood occurrences in remaining months December and March is not so distinct. The MD with December occurrences (7.8\%) is nearly entirely linked with water courses draining areas of the Šumava and the Novohradské hory. The March data of MD (12.4\%) were connected with water courses in the south-eastern area of the Českomoravská vrchovina, the Dyje River Basin and the eastern part of the Czech Republic.

Based on the graphical space-time expression of the MD distribution (Fig. 5 and 6) it is obvious that in some water courses, particularly in the Odra River Basin, the flood discharges in the winter half year during the reference period 1975-2000, did not, with small exceptions, take place at all. This also confirms the significant flood seasonality in summer periods in this river basin. 


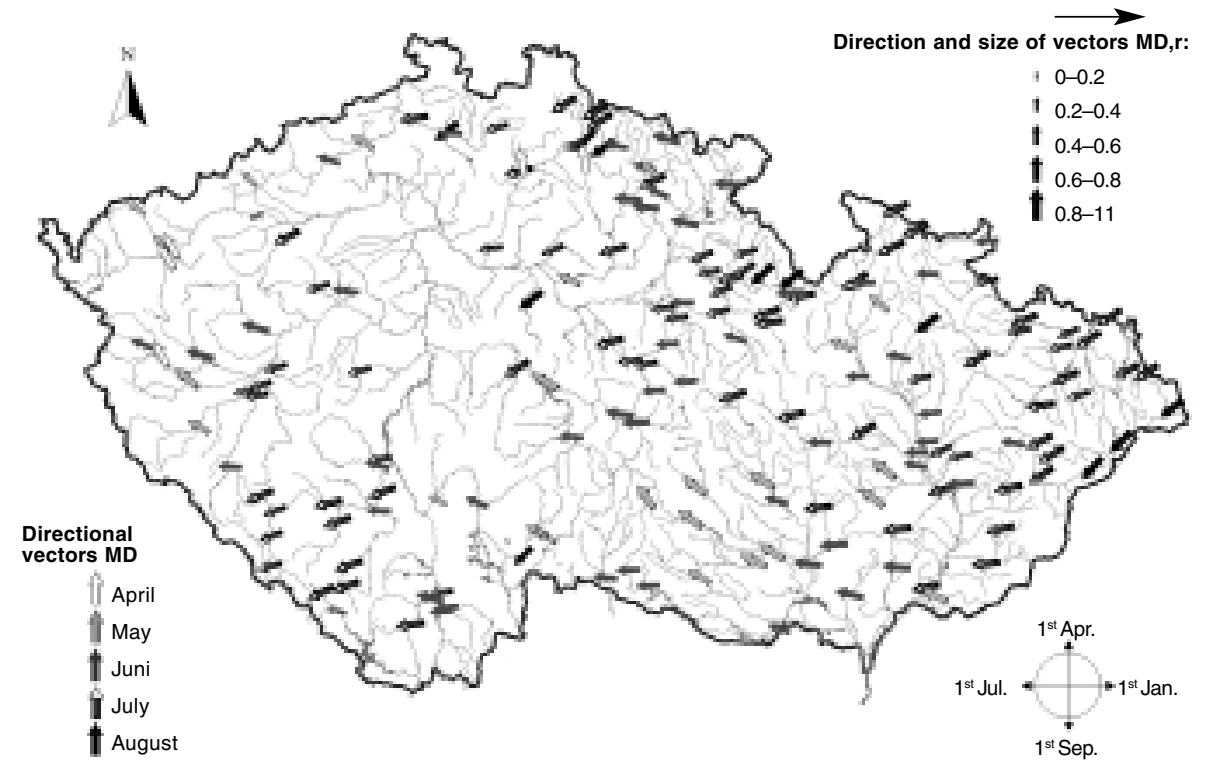

Figure 7: Presentation of mean flood events occurrence (MD) in selected profiles in vegetation period April - August during the reference period 1975-2000

In the map of Fig. 7 the results of seasonal analysis of summer flood events in all selected gauging stations are presented. Average datum of MD in the summer half of year from all stations fell on $26^{\text {th }}$ June. Comparison of summer months in the searched period shows that the highest number MD in this part of the year occurs in July (47\% cases were found out) and in June (30\%). Geographical gauging station locations, theirs MD of summer floods belong to the same months, allow to consider that the average datum of MD delay slowly in the eastern direction. This phenomenon is confirmed even by average values of MD in the main river basins. In the most eastern laying the Odra River Basin the average datum of MD falls on $20^{\text {th }}$ August, what is two months later than the average flood occurrences in the Labe River Basin. The dispersion $r$ of summer flood event occurrences shows that the highest flood occurrence seasonality ( 0.89 and 0.88 were found out) belongs to water courses in the Dyje and the Odra River Basins respectively. In general, the very highest seasonal dispersion is in water courses of the Labe River Basin.

\section{Conclusions}

Results of the seasonal analysis of flood event occurrences in 181 selected gauging stations during the reference period 1975-2000 prove differences of the flood load in the Czech Republic territory with the flood disaster in individual periods of year. This was even the reason of working out this study: to find and to identify periods and regions where higher or more frequent floodings occur. 
Application of directional characteristic method for the period 1975-2000 showed that the mean day of the flood events occurrence during year (MD) in the Czech Republic territory is $24^{\text {th }}$ April. It proves the predominance of mixed flood occurrences with higher winter regime component. Therefore the highest number of MD in February and March responds to the significant share of winter floods (December $10.9 \%$, January $11.8 \%$, February $8.8 \%$ and March $22.4 \%$ ). The influence of the summer component of flood regime has response even in dates of MD in July. On the contrary, the months with the lowest flood frequencies, i.e. with the periods of relative rest of floods, are the autumn months September and October. This means that during the year there are two different periods with higher flood occurrence frequencies in the Czech Republic rivers. The first of them is represented by winter months. This is the period with winter and spring floods which are formed by snow cover melting in combination with rainfalls. The second period, characterized by flood unrest, is represented by summer months July and August. For them the summer floods are typical. They are formed by long lasting regional rainfalls or by short lasting torrent rainfalls of high intensity. Space-time flood occurrence distribution with indication of their average seasonal frequency probability was found out and it is presented for the whole year and as well as for cold and warm periods of year in maps in Fig. 4, 6 and 7.

Analysis of the whole year flood occurrences also proves that there is even a significant difference of flood regimes between the eastern part of the Czech Republic, particularly of the Odra River Basin and its other parts, whereas water courses in Bohemia and partly in southern and western Moravia have the potential possibility of the flood occurrences exist nearly in all months of the year.

Application of directional characteristic method on data belonging only to the selected winter or vegetation periods in the reference period 1975-2000 enabled to identify more exactly days with higher flood event occurrence risk in individual river basins. Magnitudes of index $r$, which identifies dispersion of flood events during the year, show that the lowest flood occurrence dispersion is in water courses of the Odra and the Dyje River Basins and, on the other hand, the highest ones are in rivers of the Labe River Basin.

\section{References}

BAYLISS, A.C., JONES, R.C. (1993): Peaks over Threshold flood database: Summary statistics and seasonality. Report No. 121. Institute of Hydrology, Wallingford, UK.

BLACK, A.R., WERRITTY, A. (1997): Seasonality of flooding: a case study of North Britain. Journal of Hydrology 195.

BRÁDKA, J. (1967): Meteorologické příčiny povodní ve Slezku. Meteorologické zprávy 20, ČHMÚ, Praha, 3-9.

BUCHTELE, J. (1972): Kategorizace povodňového režimu na tocích vltavské kaskády. Sborník prací HMÚ, sv. 18, Praha, 65-139.

ČEKAL, R. (2007): Analýza atmosférických příčin povodní na př́padu povodí horní Ohře. In: Povodně a změny v krajině. Edit. J. Langhammer. Univerzita Karlova v Praze, Př́rodovědecká fakulta, Katedra fyzické geografie a geoekologie, Praha, 113-121.

FISHER, N. I. (1993): Statistical Analysis of Circular Data. Cambridge University Press, Cambridge, UK. HLADNÝ, J. (1971): K rajonizaci povodňových situací na území ČSR pro potřeby povodňové služby. Sborník referátů z hydrologické konference v Brně, Studia Geographica 22, GÚ ČSAV, Brno, 221-236. 
HLADNÝ, J., CHALUŠOVÁ, J., VLASÁK, T. (2001): Hydrosynoptic approaches for identification of flood mechanisms. Acta Universitatis Carolinae, Geographica, No. 2, Praha, 81-98.

CHALUŠOVÁ, J., HLADNÝ, J., ČEKAL, R. (2007): Regionalizace povodí Labe na základě sezonální analýzy výskytu povodní. In: Povodně a změny v krajině. Edit. J. Langhammer. Univerzita Karlova v Praze, Př́rodovědecká fakulta, Katedra fyzické geografie a geoekologie, Praha, 91-100.

KAKOS, V. (1983): Hydrometeorologický rozbor povodní na Vltavě v Praze za období 1873-1982. Meteorologické zprávy 38 (5), ČHMÚ, Praha, 171-181.

KAŠPÁREK, L. A KOL. (1999): Hodnocení modelování srážko-odtokových vlastností povodí. VÚV T. G. Masaryka, Praha.

MARDIA, K. V. (1972): Statistics of Directional Data. Academia Press, London.

NETOPIL, R. A KOL. (1984): Fyzická geografie 1. Státní pedagogické nakladatelství, Praha.

OUARDA, T.B.M.J., ASHKAR, F., EL-JABI, N. (1993): Peaks Over Threshold Model for Seasonal Flood Variations. Engineering Hydrology, USA, 341-346.

ŠERCL, P., LETT, P. (2002): Výpočet rastru srážek v prostř̌edí GIS (s využitím ArcView Spatial Analyst). Uživatelská príručka verze 2.0.1, OPV ČHMÚ, Praha.

TODOROVIC, P., ZELENHASIC, E. (1970): A stochastic model for flood analysis. Water Resources Research, 6 (6).

VAVRUŠKA, F. (1989): Meteorologické př́íčiny povodní na Otavě a Lužnici. Meteorologické zprávy, 42. ČHMÚ, Praha, 111-115.

\section{Résumé \\ Analýza sezonality výskytu povodní na území České republiky metodou směrových charakteristik}

Analýza sezonality výskytu povodní př̌edstavuje jeden z ambiciózních metodologických př́stupů ke zvýšení poznatků o režimu těchto prírodních disturbancí. K aplikaci analýzy na území České republiky bylo použito údajů ze 181 vodoměrných stanic (z toho 108 z povodí Labe, 21 z povodí Odry a 52 z povodí Moravy a Dyje). Vstupními veličinami byly povodňové průtoky reprezentované jejich denními průměry v jednotném referenčním období 1975-2000. K vyjádření prostorové odlišnosti sezonality výskytu povodní byla použita metoda směrových statistik. Výstupem postupů podle této metody je určení průměrného dne výskytu povodní (MD) v průběhu roku v šetřeném povodí a dále index časového rozptylu (r) povodňových př́ípadů.

Na základě těchto směrových charakteristik aplikovaných na souborech vybraných povodí lze tak území České republiky rozdělit na oblasti podle četnosti výskytu povodní v konkrétním období roku.

RNDr. Radek Čekal, Ph.D.

Czech Hydrometeorogical Institute

Na S̆abatce 17

14306 Prague 4

Czech Republic

e-mail:cekal@chmi.cz.

phone: +420606535103

Ing. Josef Hladný, CSc.

Czech Hydrometeorogical Institute

Na Šabatce 17

14306 Prague 4

Czech Republic

e-mail: hladny@chmi.cz

phone: +420 244032354 